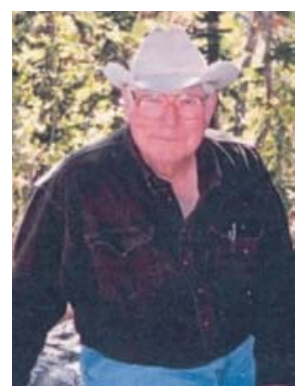

Thad Box

\title{
Grassland, Earthsongs, and Exurbia
}

A recurring theme in my writing has been that we must listen to the land. We hear its songs of happiness or groans of pain as humans stroke it with their varied uses. When we hear cries of anguish, we attempt to rescue it with our science and action programs. We design new research to produce lyrics for the earthsongs we hear. We develop educational efforts to teach both private owners and government agencies about how science can heal wounded land.

Range management came into existence when overgrazing and drought stripped the land of its protective cover during the last half of the 19th century. Pioneer botanists heard the earth scream and our founders spoke elegantly. Concepts of ecological management of native ranges developed and were tested by controlled experiments. Gradually, we became the authorities on overgrazing, the causes of deterioration, and the conditions of stability.

Perhaps the range profession was born to write the grand opera of herbivory's interaction with people and land. The stage was set for the cries, groans, and yells screamed by eroding land to be answered by passionate, powerful voices of science. Earthsongs detailed the drama of destruction and resurrection, insanity and reason.

In the early days, efforts were directed overwhelmingly toward seeking ways for the interaction of domestic livestock and rangelands to become economically sustainable. Somewhere along the way earthsongs were replaced by cowboy ballads. Many of our lyrics and music reflected what we heard from people seeking wealth, not from voices of the land. But all rangelands were not suitable for commercial livestock production, and rangeland use changed in ways our founders never imagined.

A little over a decade ago, Bob Whitson was appointed range department head at Texas A\&M. The department arranged a retreat and the faculty, clients, and friends got together to assess the department's program and examine future needs of Texas' rangelands. I was invited to be part of my alma mater's self-examination.

The assessment of the department's past was a celebration of success. Texas has the nation's most rangelands, almost all in private ownership. Some of the oldest, largest, and best-known ranches are there. The department had an admirable record of working with ranchers. It had good faculty who did practical research. Its graduates filled important jobs in both the public and private sector. Looking back at its past, it appeared all that was needed was some fine-tuning.

However, when the group looked at what was then present, they saw that Texas had changed. The number, and total acreage, of large commercial ranches they served had decreased. Many counties that were ranching areas when the department was established had become bedroom communities for metropolitan areas. Ranches had been cut into "ranchettes," made into housing developments, or otherwise changed from livestock production. Even the commercial ranches were making more money from leasing hunting privileges than from domestic animals. 
Commercial ranches were still important, and the department needed to continue to serve them. But rangelands were being used for different things. Many of the properties were too small to carry the ponies and emus that were kept on them. It was obvious that if the department continued the way it had been in the past, it would speak for a declining percentage of the state's rangelands. Its potential for service would be lost by looking in the rearview mirror.

I left the retreat pleased that my alma mater had forced itself to look at actual rangeland use instead of living in the past. I'll leave it to someone from Texas A\&M to write about their successes and failures in addressing the needs of changing Texas rangelands. But our profession should look at both their successes and their failures, and learn from them. It is especially important to know why their failures failed. Or why they decided it was not their role to address some apparent new rangeland needs.

One of the most important measures of the value of range professionals is how well we adapt to the changing use of the land we serve. Our choice of which lands to address and which ones to leave for others will not only define us for future generations, it may well determine whether we survive as a profession. Not only must we listen to land, but we must also listen for signals of major societal changes.

A new land-use category has emerged: exurbia. Most of us know that people in the sprawl of upscale homes beyond suburbia voted heavily for President Bush. Houses nestled among the pines on western ranges are front-page news during fire season, and taxes must be raised to bring basic services to the scattered mansions.

Most of our discussion about this spreading land use has been political or economic:
Who lives there? How do they vote? What does their lifestyle cost the taxpayer? Who subsidizes their existence?

Exurban sprawl raises important questions for the range profession: How small a chunk of rangeland will we defend? Will we claim rangelands only if it produces a commodity?

Are small parks of natural "open space" our responsibility? Are 5 acres of native grass cut by a riding lawn mower considered rangelands? Would city lots managed by ecological principles or those managed by turf agronomy be better for environmental quality?

If we decide to accept the responsibility of applying ecology to all land, other questions are raised: How will we restructure our research to serve small, noneconomic pieces of rangeland? Is social science research such as evaluating golfer acceptance of buffalo grass fairways range research? Must something eat the vegetation for us to claim it as rangeland?

Is biological control of insects on exurban lots part of the grand opera of herbivory? What about maintaining ecological balance of native animals and plants on national monuments? Is increase of King Ranch bluestem in road rights-ofway and other ungrazed areas a range problem?

The grand opera of rangelands is ever expanding. We should not, cannot, abandon the fiddle tunes of the old West. But in exurbia the land is screaming loudly as it is torn asunder by big yellow backhoes. Its wounds are covered with Band-Aids ${ }^{\circledR}$ of concrete and asphalt. Land is treated with insecticides and chemical fertilizer and groomed with mowers gulping fossil fuel. How we use our science and our ecological experience to write new melodies of sustainability for land so treated will determine who we are, what we call ourselves, and if we should exist in today's world. 